\title{
Cost effectiveness of heptavalent pneumococcal conjugate vaccine in populations of high risk in Colombia
}

\author{
Nelson Alvis Guzmán, PhD¹, Fernando De la Hoz, MD²
}

\section{SUMMARY}

Objective: To estimate the economic impact of the introduction of heptavalent pneumococcal conjugate vaccine (PCV7) in high risk populations of Colombia.

Methods: A full economic evaluation was done regarding potential introduction of PCV-7. A cost-effectiveness study from the perspective of the third payer was done using a Decision Model. The model considered two alternatives: with and without vaccination. As measurement of results the avoided events were taken [cases, hospitalizations, deaths and Life-Years Saved (LYS)]. In addition the net costs and the incremental cost-effectiveness ratio (ICER) were evaluated.

Results: In a cohort of 70 thousand children of under 2 years old in situation of high risk, can generate 532 deaths that would produce a little more than 21 thousand Years of Life Lost (YLL) with costs between 7.7 and 13.3 million dollars. If we vaccinate this same cohort the deaths can be reduced to 355 , and the costs of burden of disease would be between 5.7 and 10 million dollars. It is estimated a reduction of $25 \%$ of the costs of burden of disease and of $33 \%$ of the deaths. In addition the ICER by YLS would be between 590 and 762 dollars.

Conclusion: The introduction of the Heptavalent Pneumococcal Conjugate Vaccine in populations of high risk is highly cost effective in Colombia.

Colomb Med. 2010; 41: 315-22

Keyword: Cost effectiveness; Vaccination; Pneumococcal vaccine; High risk; Pneumonia.

Costo efectividad de la vacuna conjugada heptavalente de neumococo en poblaciones de alto riesgo en Colombia. El caso de la vacunación en niños de bajo peso al nacer

\section{RESUMEN}

Objetivo: Evaluar económicamente la introducción de la vacuna heptavalente de neumococo en poblaciones de alto riesgo en Colombia.

Métodos: Se realizó un análisis de costo-efectividad desde la perspectiva del tercer pagador utilizando un modelo de decisiones que consideró dos alternativas: con y sin programa de vacunación. Como medida de resultados se tomaron los eventos evitados [casos, hospitalizaciones, muertes y años de vida salvados (AVS)]. Además, se valoraron los costos netos y la razón de costo-efectividad incremental (RCEI).

Resultados: En una cohorte de 70 mil niños menores de dos años en situación de alto riesgo (bajo peso al nacer), se puede generar 532 muertes que producirían un poco más de 21 mil años de vida perdidos. Los costos de atención estarían entre 7,7 y 13,3 millones de dólares. Si vacunásemos esta misma cohorte con la vacuna conjugada heptavalente las muertes se reducirían a 355 y los costos de la carga estarían entre 5,7 y 10 millones de dólares. Es decir, una reducción cerca de $25 \%$ de los costos de la carga y 33\% de las muertes. Además el RCEI por AVS estaría entre 590 y 762 dólares del año 2006.

Conclusiones: La introducción de la vacuna contra neumococo en poblaciones de alto riesgo (bajo peso al nacer) en Colombia es altamente costo-efectiva.

Colomb Med. 2010; 41: 315-22

Palabras clave: Costo efectividad; Vacunación; Neumococo; Alto riesgo; Neumonía.

1. Professor, Economic Science Faculty, Universidad de Cartagena, Cartagena, Colombia. e-mail: nalvis@yahoo.com

2. Professor, Public Health Department, Universidad Nacional de Colombia, Bogotá, Colombia.

e-mail: fpdelahozr@unal.edu.co

Received for publication July 23, 2009 Accepted for publication May 7, 2010 
The success of the PAI strategy to improve health has lead to improve the development of new vaccines to battle other health diseases, such as pneumonia, meningitis, hepatitis A, varicella and rotavirus. These new vaccines have shown to have high efficacy and safety, and promise to reduce even more the burden of disease in human populations. However, due to the high vaccineintroduction prices in the market, the more vulnerable population, the poorest without health insurer, are those who benefit the least with this technological advances.

It is estimated that around a million children less than 5 years old die annually due to invasive infections associated to Streptococcus pneumoniae, even when there are two polysaccharides vaccines in children under 2 years. One of the vaccines, the most extensively assessed, has seven serotypes that cause more than $85 \%$ of the disease in United Sates, but have a lower coverage in Colombia ${ }^{1}$. The serotypes in this vaccine are $4,23 \mathrm{~F}$, $6 \mathrm{~B}, 19 \mathrm{~F}, 18 \mathrm{C}, 14$ and $9 \mathrm{~V}$, which have an average coverage of $62 \%$ for pneumococcal invasive disease in Colombia. This is due to the lack of coverage of serotypes 1 and 5 that frequently cause invasive disease in our country and Latin America ${ }^{2}$. This event, tied to the high cost of the vaccine, should encourage carefulness in the analysis of the burden of disease of the possible introduction of the vaccine and the balance of the possible benefits of its introduction versus the cost. One of the possible ways of action is to introduce the vaccine in high risk populations, low birth weight, that have a much higher incidence of pneumococcal disease compared with normal weight children ${ }^{3-5}$. The present study makes a cost-effectiveness analysis of the heptavalent vaccine against pneumococco in high risk populations of Colombia.

\section{METHODS}

To estimate the burden of disease of pneumococco in high risk populations a model with the low birth weight population under two years was done. It is estimated that approximately $8-10 \%$ of Colombian children born with less than $2,500 \mathrm{~g}$, which represents an annual cohort of 70,000 children. For the present study it was assumed that children of two cohorts of live births were followed from birth until two years of age. One of the cohorts simulated a population without vaccination, and the other assumed $90 \%$ of the children received 3 doses of PCV-7. To estimate epidemiologic parameters of frequency of disease and cost, information about occurrence of invasive disease and pneumonia due to pneumococcal disease in Latin America, from a review realized by Savin Vaccine Institute in $2006^{6}$. It was assumed that risk of disease for each pneumococcalrelated syndrome was twice for children with low birth weight, compared with normal birth weight ${ }^{5}$. The estimations from the Sabin study are in Table 1.

The vaccine used in this analysis is a conjugated vaccine of seven serotypes, produced by Wyeth $\AA$. Efficacy and effectiveness of the heptavalent vaccine have been extensively assessed in United States, but there are still few studies of its effectiveness in other countries, especially in developing countries. The effectiveness of the vaccine for this study was estimated from the studies of Black et $\mathrm{al}^{17,18}$. About the serotypes of the vaccine, the adjustment because of the serotype distribution in Colombia was not considered. A mean cost of the vaccination was considered to be US\$35 per dose, which it is the price offered by Fondo Rotatorio de Vacunas of Pan-American Health Organization (PAHO). For the sensitivity analysis the price varied US\$5.

To perform the cost-effectiveness analysis a decision tree model was design (Figure 1), with two branches that considered two alternatives (vaccination and not vaccination). To model the decision tree the parameters in Table 2 were used. Data was incorporated and processed in a Microsoft Excel ${ }^{\circledR} 2007$ spreadsheet.

Temporal horizon and perspective. For the analysis cost and health outcomes of a cohort of children less than two years old were assessed, for a year (after vaccination), from the third payer perspective. For international comparability, costs were expressed in American dollars of 2006.

Outcome measures. As model outcome measures avoided events were taken (cases, hospitalizations, deaths, and life-years saved). Also, regarding the costs, net costs and incremental cost-effectiveness (ICER) were assessed. For the present study, ICER is the difference between vaccination costs minus avoided treatment cost, divided by life-years saved (LYS), as shown in the following formula:

ICER =

Vaccination-related cost - Avoided treatment costs 
Table 1

Incidence of pneumococco related disease

Age group

Median of incidence per $10^{5}$ (Q1-Q3) Number of studies (References)

\begin{tabular}{|c|c|c|}
\hline \multicolumn{3}{|c|}{ Invasive pneumococcal disease } \\
\hline$<1$ yr old & $61(58-63)$ & $2(7,8)$ \\
\hline$<2$ yrs old & $61(52-71)$ & $2(7,8)$ \\
\hline$<5$ yrs old & $32(32-33)$ & $1(8)$ \\
\hline \multicolumn{3}{|c|}{ Pneumococcal meningitis } \\
\hline$<1 \mathrm{yr}$ old & 19 & $1(9)$ \\
\hline$<2$ yrs old & 12 & $1(9)$ \\
\hline$<5$ yrs old & 12 & $4(8,10-12)$ \\
\hline \multicolumn{3}{|c|}{ All-cause pneumonia } \\
\hline$<2$ yrs old & 4363 & $1(13)$ \\
\hline$<5$ yrs old & 3059 (2957-3142) & $2(13,14)$ \\
\hline \multicolumn{3}{|c|}{$\begin{array}{l}\text { All-cause radiological } \\
\text { confirmed pneumonia }\end{array}$} \\
\hline$<2$ yrs old & 2100 (1723-2375) & $4(7,13,15,16)$ \\
\hline$<5$ yrs old & $1174(980-1613)$ & $3(13,15,16)$ \\
\hline \multicolumn{3}{|c|}{ Pneumococcal pneumonia } \\
\hline$<2$ yrs old & $51(417-55)$ & $2(7,9)$ \\
\hline$<5$ yrs old & 34 & $1(8)$ \\
\hline \multicolumn{3}{|c|}{ Pneumococcal sepsis } \\
\hline$<3$ yrs old & 2 & $1(8)$ \\
\hline
\end{tabular}

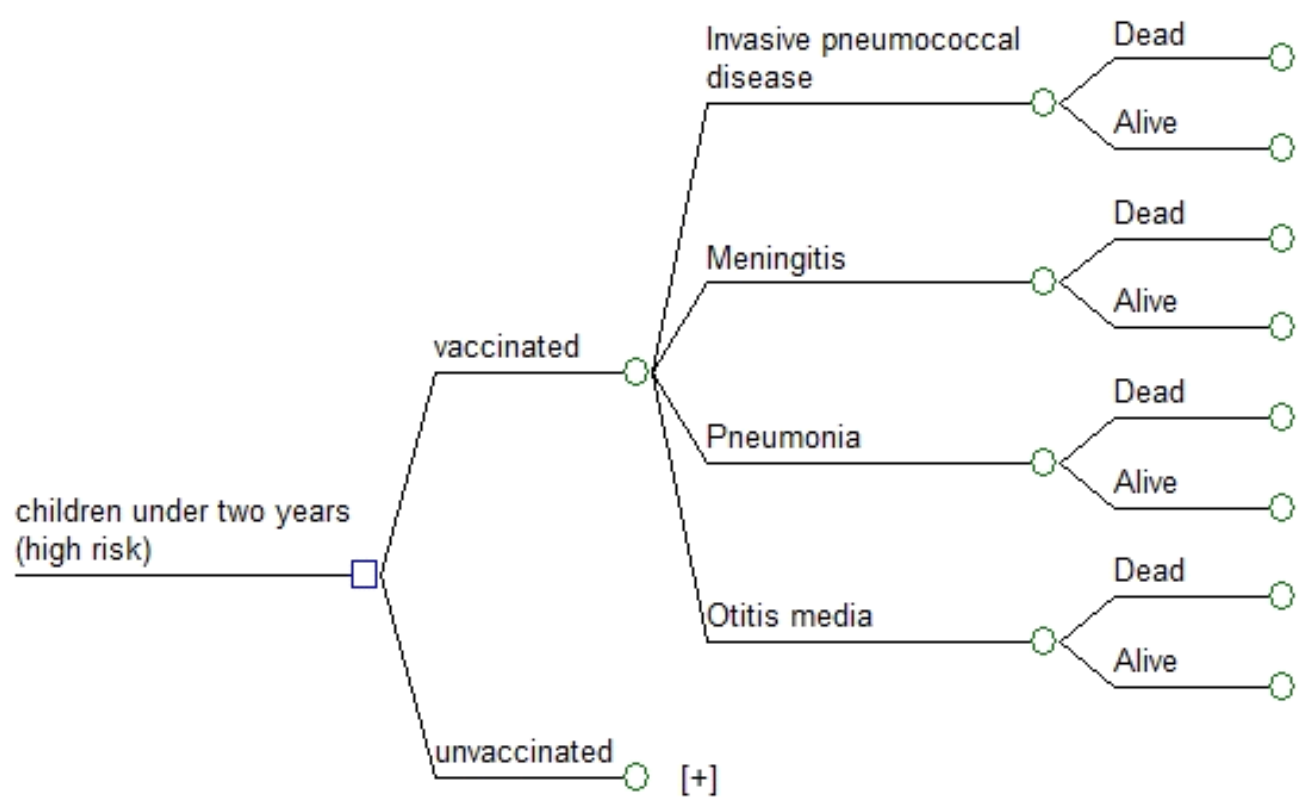

Figure 1. Decision tree to assess the cost-effectiveness of the introduction of the heptavalent vaccine in population under 2 years old with high epidemiological risk in Colombia. 
Table 2

Parameters for the economic assessment of PCV-7 in high risk populations

\begin{tabular}{|c|c|c|c|c|}
\hline \multirow[t]{2}{*}{ Model parameters } & \multirow[t]{2}{*}{ Base } & \multicolumn{2}{|c|}{ Plausible range } & \multirow[t]{2}{*}{ References } \\
\hline & & Inferior limit & Superior limit & \\
\hline \multicolumn{5}{|l|}{ Demographic } \\
\hline Population $<2$ yrs old at risk & 70 mill & - & - & Actual analysis \\
\hline Life expectancy $<2$ yrs old & 72,0 & - & - & \\
\hline Discount rate & $3 \%$ & & & \\
\hline Disease incidence & Table 1 & & & \\
\hline \multicolumn{5}{|l|}{ Attention cost (U\$ 2006) } \\
\hline Invasive pneumococcal disease & 1300,5 & 1132,38 & 1543,26 & (6) \\
\hline Meningitis & 1303,7 & 1059,24 & 2761,42 & \\
\hline Clinically-diagnosed pneumonia & 92,5 & 77,82 & 220,59 & \\
\hline Radiological-diagnosed pneumonia & 885,9 & 866,93 & 1325,29 & \\
\hline Pneumococcal pneumonia & 885,9 & 866,93 & 1325,3 & \\
\hline Otitis media & 93,9 & 90,7 & 170,05 & \\
\hline \multicolumn{5}{|l|}{ Efficacy of pneumococcal vaccination } \\
\hline Invasive pneumococcal disease & 0,65 & 0,60 & 0,75 & $(17,18)$ \\
\hline Meningitis & 0,65 & 0,60 & 0,75 & \\
\hline Clinically-diagnosed pneumonia & 0,12 & 0,70 & 0,15 & \\
\hline Radiological-diagnosed pneumonia & 0,20 & 0,15 & 0,25 & \\
\hline Pneumococcal pneumonia & 0,65 & 0,60 & 0,75 & \\
\hline Otitis media & 0,07 & 0,04 & 0,10 & \\
\hline Number of vaccine doses & 3 & & & $\begin{array}{l}\text { Ministerio de la } \\
\text { Protección Social }\end{array}$ \\
\hline Cost for each vaccine dose & U\$35 & U\$5 & U\$35 & \\
\hline Addministrative cost for each vaccine dose & U\$1.0 & U\$0.5 & U\$1.50 & \\
\hline
\end{tabular}

As the recommended by WHO's Commission on Macroeconomics and Health ${ }^{19}$ a strategy was considered very cost-effective if the cost for avoided DALY is less than the gross domestic product (GDP) per capita; if that cost was below three times the GPD per capita, the strategy was considered cost-effective; finally, if it is above three times the GDP per capita, the strategy is not cost-effective. For Colombia, according to Banco de la República, in 2006 the GDP per capita was US\$3,745.

Sensitivity analysis. To evaluate the robustness of the results, a deterministic univariate sensitivity analysis was performed, using inferior and superior epidemiologic and cost parameters, as shown in Table 2 . Also, a scenario analysis was performed simulating the best and worst epidemiologic scenario with base on the disease incidence.

\section{RESULTS}

In a cohort of 70 thousands children under two years of age with low birth weight $(<2,500 \mathrm{~g})$, there are 532 generated deaths as a product of the events related in Table 3 . These deaths would produce 21 thousand years of life lost, with cost between 7.7 and 13.3 million dollars. If we vaccinate that same cohort, deaths could be reduce to 355, and burden cost would be between 5.7 and 10 million dollars. That means a reduction of nearly $25 \%$ of the burden costs and $33 \%$ of deaths. 
Table 3

Cost of pneumococcal burden of disease in children less than 2 years old with high epidemiological risk Colombia 2007 (2006 US\$)

\begin{tabular}{|c|c|c|c|c|c|c|}
\hline \multirow{2}{*}{$\begin{array}{l}\text { Events and cost with } \\
\text { vaccination }\end{array}$} & \multicolumn{2}{|c|}{ Expected } & \multirow{2}{*}{$\begin{array}{c}\text { Years of } \\
\text { life lost }\end{array}$} & \multicolumn{3}{|c|}{ Total cost } \\
\hline & cases & deaths & & Total & Inf lim & Sup lim \\
\hline Invasive pneumococcal disease & 35 & 14 & 560 & $46.620,0$ & $39.633,3$ & $54.014,1$ \\
\hline Meningitis & 35 & 14 & 560 & $46.830,0$ & $37.073,4$ & $96.649,7$ \\
\hline Clinically-diagnosed pneumonia & 11.200 & 224 & 8.960 & $1.030 .400,0$ & $871.584,0$ & $2.470 .608,0$ \\
\hline Radiological-diagnosed pneumonia & 5.600 & 112 & 4.480 & $4.961 .600,0$ & $4.854 .808,0$ & $7.421 .624,0$ \\
\hline Pneumococcal pneumonia & 1.400 & 168 & 6.720 & $1.240 .400,0$ & $1.213 .702,0$ & $1.855 .420,0$ \\
\hline Otitis media & 7.875 & - & - & $732.375,0$ & $714.262,5$ & $1.339 .143,8$ \\
\hline Total & & 532 & 21.280 & 8.058 .225 & 7.731 .063 & 13.237 .460 \\
\hline \multicolumn{7}{|l|}{ Events and costs with vaccination } \\
\hline Invasive pneumococcal disease & 12 & 5 & 196 & $16.317,0$ & $13.871,7$ & $18.904,9$ \\
\hline Meningitis & 12 & 5 & 196 & $16.390,5$ & $12.975,7$ & $33.827,4$ \\
\hline Clinically-diagnosed pneumonia & 9.856 & 197 & 7.885 & $906.752,0$ & $766.993,9$ & $2.174 .135,0$ \\
\hline Radiological-diagnosed pneumonia & 4.480 & 90 & 3.584 & $3.969 .280,0$ & $3.883 .846,4$ & $5.937 .299,2$ \\
\hline Pneumococcal pneumonia & 490 & 59 & 2.352 & $434.140,0$ & $424.795,7$ & $649.397,0$ \\
\hline Otitis media & 7.324 & - & - & $681.108,8$ & $664.264,1$ & $1.245 .403,7$ \\
\hline Total & & 355 & 14.213 & 6.023 .988 & 5.766 .747 & 10.058 .967 \\
\hline \multirow{2}{*}{$\begin{array}{l}\text { Avoided events and cost } \\
\text { with vaccination }\end{array}$} & \multicolumn{2}{|c|}{ Expected } & Years of & \multicolumn{3}{|c|}{ Total cost } \\
\hline & cases & deaths & life lost & Total & Inf lim & Sup lim \\
\hline Invasive pneumococcal disease & 23 & 9 & 364 & $30.303,0$ & $25.761,6$ & $35.109,2$ \\
\hline Meningitis & 23 & 9 & 364 & $30.439,5$ & $24.097,7$ & $62.822,3$ \\
\hline Clinically-diagnosed pneumonia & 1.344 & 27 & 1.075 & $123.648,0$ & $104.590,1$ & $296.473,0$ \\
\hline Radiological-diagnosed pneumonia & 1.120 & 22 & 896 & $992.320,0$ & $970.961,6$ & $1.484 .324,8$ \\
\hline Pneumococcal pneumonia & 910 & 109 & 4.368 & $806.260,0$ & $788.906,3$ & $1.206 .023,0$ \\
\hline Otitis media & 551 & - & - & $51.266,3$ & $49.998,4$ & $93.740,1$ \\
\hline Total & & 177 & 7.067 & $2.034 .236,8$ & $1.964 .315,7$ & $3.178 .492,3$ \\
\hline
\end{tabular}

To vaccinate 70 thousands children with the three doses of the PCV-7 cost 7.3 million dollars, which would avoid treatment cost between 2 and 3.2 million dollars. This will generate net cost between 4.1 and 5.3 million dollars. With these costs, ICER of life-yearssaved would be between 590 and 762 dollars, and ICER of avoided death would be between 23,611 and 30,483 dollars (Table 4).

For the sensitivity analysis an on-way analysis was done with all variables that entered in the model, which established which variables influenced the model the most. These variables, for the present model, were cumulative incidences of pneumococcal invasive disease and pneumonias. With these results, different epidemiologic scenes (best and worst) were defined. ICER results of life-years saved between 845 and 1026 US\$/LYS (best scene), and 422 and 489 US\$/LYS (worst scene) (Table 4).

\section{DISCUSSION}

The results of the present study suggest that 
Table 4

Net costs and ICER of the Colombian vaccination program in chldren less than 2 years old with high epidemiological risk Colombia 2007 (2006 US\$)

\begin{tabular}{|c|c|c|c|}
\hline Base epidemiological scene & Base case & Inf lim & Sup lim \\
\hline Direct costs of attention & 8.058 .225 & 7.731 .063 & 13.237 .460 \\
\hline Vaccination costs & 7.350 .000 & 7.350 .000 & 7.350 .000 \\
\hline Avoided cost of after vaccination & 2.034 .237 & 1.964 .316 & 3.178 .492 \\
\hline Net costs & 5.315 .763 & 5.385 .684 & 4.171 .508 \\
\hline ICER U\$/LYG & 752 & 762 & 590 \\
\hline ICER U\$/avoided death & 30.087 & 30.483 & 23.611 \\
\hline Worst epidemiological scene & Caso base & Lim inf & Lim sup \\
\hline Direct costs of attention & 9.281 .839 & 8.907 .847 & 15.234 .615 \\
\hline Vaccination costs & 7.350 .000 & 7.350 .000 & 7.350 .000 \\
\hline Avoided cost of after vaccination & 2.397 .654 & 2.315 .913 & 3.740 .849 \\
\hline Net costs & 4.952 .346 & 5.034 .087 & 3.609 .151 \\
\hline ICER U\$/LYG & 579 & 589 & 422 \\
\hline ICER U\$/avoided death & 23.166 & 23.548 & 16.883 \\
\hline Best epidemiological scene & Caso Base & Lim Inf & Lim Sup \\
\hline Direct costs of attention & 6.980 .435 & 6.696 .497 & 11.506 .943 \\
\hline Vaccination costs & 7.350 .000 & 7.350 .000 & 7.350 .000 \\
\hline Avoided cost of after vaccination & 1.681 .027 & 1.622 .673 & 2.634 .801 \\
\hline Net costs & 5.668 .973 & 5.727 .327 & 4.715 .199 \\
\hline ICER U\$/LYG & 1.015 & 1.026 & 845 \\
\hline ICER U\$/avoided death & 40.615 & 41.033 & 33.781 \\
\hline
\end{tabular}

Table 5

Cost-effectiveness of the interventions for the treatment of acute respiratory disease due to pneumonia (2001 Dollars/DALY)

\begin{tabular}{|c|c|c|c|c|c|}
\hline \multirow[t]{2}{*}{ Region } & \multicolumn{3}{|c|}{ Non severe (level) } & \multirow{2}{*}{$\begin{array}{c}\text { Severe } \\
\text { hospital level }\end{array}$} & \multirow{2}{*}{ All the interventions } \\
\hline & community & institutional & hospital & & \\
\hline Low and middle income-countries & 208 & 50 & 2.916 & 6.144 & 398 \\
\hline East-Asia and Pacific & 439 & 91 & 6.511 & 13.945 & 900 \\
\hline Latin America and the Caribbean & 547 & 424 & 14.719 & 28.106 & 1.941 \\
\hline Middle-east and north Africa & 733 & 180 & 6.810 & 13.438 & 1.060 \\
\hline South Asia & 140 & 28 & 1.931 & 4.318 & 264 \\
\hline Sub-Saharan Africa & 139 & 24 & 1.486 & 3.376 & 218 \\
\hline
\end{tabular}

Source: Reference 24 
vaccination against pneumococco in children of low birth weight is very cost-effective. There is a high possibility that the results are conservative, because we assumed the risk of acquiring pneumococcal disease in children with low birth weight to be twice compared with the children with normal birth weight. It is possible that this risk is really higher, as some studies in Colombia have shown ${ }^{20}$.

The economic evaluation of the incorporation of the PCV-7 in national programs of vaccination has been studied in developed countries, showing ICER is highly sensitive to vaccine prices and the incorporation of vaccination herd immunity. In Norway, for example, for a $\mathbf{\bullet} \$ 54$ vaccine dose, the vaccination is not costeffective at a threshold of 54 thousands Euros for $\mathrm{LYG}^{21}$. Similar results are present in Canada, when it is concluded that only with a vaccine below 30 dollars per dose, costs from the societal perspective would be save $^{22}$.

On the other hand, Beutels et al. ${ }^{23}$, in a review of 15 studies of the vaccine economic evaluation, establish that Finland, Australia, England, Netherlands, and Canada, the pneumococcal vaccination against pneumococco (PCV7) was reported less cost-effective than dialysis and screening for breast cancer (Finland); screening of cervical or breast cancer (Australia), vaccination against meningococcus $\mathrm{C}$ or influenza (Netherlands), vaccination against pneumococco in adults (with pneumococcal polysaccharide vaccine) or varicella (Canada). Nevertheless, universal vaccination with PCV7 was cost-effective in Spain, Canada and Germany (from the societal perspective).

Table 5 shows the cost-effectiveness of assisting pneumonia cases in Latin America and the Caribbean ${ }^{24}$ and see that avoid a disability-adjusted life year(DALY) is worth 1941 dollars, while with vaccination, this study shows that with vaccination to avoid the same year of life cost around 579 dollars in the most favorable scene of vaccination and 1015 in the most unfavorable. Even in the worst scene of vaccination in our country, the cost-effectiveness results in high risk populations are much more important than developed countries $^{3,4}$.

In the present study a cost of 35 dollars per vaccine is assumed (which it is an extremely high cost for a developed country), but the epidemiological situation is different (population at risk), for which the cost- effectiveness has an acceptable margin, according to WHO parameters ${ }^{19}$. For this high risk population, a three dose vaccine with the proposed prices, the intervention with the heptavalent is in the same range of the $80 \%$ of the interventions that the country has for prevention and control (less than 1000 dollars per disability-adjusted life year). The sensitivity analysis of the scenes shows how the results are robust given the variation of epidemiological parameters.

It is important to make clear that the costeffectiveness analysis only is not the most important fundament for decision analysis. This should be accompanied with the evaluation of the budget impact on the health system that the incorporation of the new technology represents, with prices that could not be financially sustainable if the intervention were costeffective, as it happens currently with some vaccines.

The limitations the present study include the fact that cost parameters are from literature review and not from studies of disease costs for specific populations, as assumed. Besides, our model does not consider the herd immunity effect of vaccination, which could underestimate the true results of the model. However, the sensitivity analysis of minimum and maximum scenes that was made could in part correct this limitation.

Conflict of interest. None of the authors has conflicts of interest related to this study.

\section{ACKNOWLEDGEMENTS}

The authors would like to thank the Ministerio de Protección Social (Ministry of Social Protection), Programa Ampliado de Inmunizaciones, for the help in the realization of the present research.

\section{REFERENCES}

1. Agudelo CI, Moreno J, Sanabria OM, Ovalle MV, Di Fabio JL, Castañeda E. Streptococcus pneumoniae: serotype evolution and patterns of antimicrobial susceptibility in invasive isolates from 11 years surveillance (1994-2004) in Colombia. Biomedica. 2006; 26: 234-49.

2. Di Fabio JL, Castaneda E, Agudelo CI, De La HF, Hortal M, Camou T, et al. Evolution of Streptococcus pneumoniae serotypes and penicillin susceptibility in Latin America, SirevaVigia Group, 1993 to 1999. PAHO Sireva-Vigia Study Group. Pan American Health Organization. Pediatr Infect Dis J. 2001; 20: 959-67.

3. Lloyd A, Patel N, Scott DA, Runge C, Claes C, Rose M. Costeffectiveness of heptavalent conjugate pneumococcal vaccine 
(Prevenar) in Germany: considering a high-risk population and herd immunity effects. Eur J Health Econ. 2008; 9: 7-15.

4. Finn A, Booy R, Moxon R, Sharland M, Heath P. Should the new pneumococcal vaccine be used in high-risk children? Arch Dis Child. 2002; 87: 18-21.

5. Mahon BE, Ehrenstein V, Norgaard M, Pedersen L, Rothman KJ, Sorensen HT. Perinatal risk factors for hospitalization for pneumococcal disease in childhood: a population-based cohort study. Pediatrics. 2007; 119: e804-12.

6. Constenla D, Gómez E, De la Hoz F, O'Loughlin R, Sinha A, Valencia J, et al. The burden of pneumococcal disease and the cost effectiveness of a pneumococcal vaccine in Latin America and the Caribbean: A review of the evidence and a preliminary economic analysis. Washington, DC: The Albert B. Sabin Vaccine Institute (SVI); 2007. [fecha de acceso en noviembre de 2007]. URL disponible en: http://www.sabin.org/files/ attachment sabinreportfinal2.pdf

7. Tregnaghi M, Ceballos A, Ruttimann R, Ussher J, Tregnaghi $\mathrm{P}$, Peeters $\mathrm{P}$, et al. Active epidemiologic surveillance of pneumonia and invasive pneumococcal disease in ambulatory and hospitalized infants in Cordoba, Argentina. Pediatr Infect Dis J. 2006; 25: 370-2.

8. Lagos R, Muñoz A, Valenzuela MT, Heitmann I, Levine MM. Population-based surveillance for hospitalized and ambulatory pediatric invasive pneumococcal disease in Santiago, Chile. Pediatr Infect Dis J. 2002; 21: 1115-23.

9. Lagos Zuccone R, San Martín B O, Erazo L A, AvendañoBertoló A, Levine M. Epidemiología de las enfermedades invasoras causadas por Streptococcus pneumoniae en niños chilenos: proyecciones clínicas y de salud pública. Rev Chil Infectol. 2001; 18: 15-21.

10. Dickinson FO, Pérez AE. Bacterial meningitis in children and adolescents: an observational study based on the national surveillance system. BMC Infect Dis. 2005; 5: 103.

11. Reis JN, Cordeiro SM, Coppola SJ, Salgado K, Carvalho MG, Teixeira LM, et al. Population-based survey of antimicrobial susceptibility and serotype distribution of Streptococcus pneumoniae from meningitis patients in Salvador, Brazil. $J$ Clin Microbiol. 2002; 40: 275-7.

12. Asturias EJ, Soto M, Menéndez R, Ramírez PL, Recinos F, Gordillo R, et al. Meningitis and pneumonia in Guatemalan children: the importance of Haemophilus influenzae type $\mathrm{b}$ and Streptococcus pneumoniae. Rev Panam Salud Publica. 2003; 14: 377-84.

13. Hortal M EM, Iraola I, De Mucio B. A population-based assessment of the disease burden of consolidated pneumonia in hospitalized children under five years of age. Int $J$ Infect Dis. 2007; 11: 273-7.

14. Barreto ML SL, Assis AM, Araujo MP, Farenzena GG, Santos PA, et al. Effect of vitamin A supplementation on diarrhoea and acute lower-respiratory-tract infections in young children in Brazil. Lancet. 1994; 344: 228-31.

15. Gentile A, Ruvinsky R, Bakir J, Gentile F, Kupervaser M, Quiriconi M, et al. Surveillance of probably bacterial pneumonia $(P B P)$ in children less than 5 years old in two geographical areas in Argentina. 45th Interscience Conference on Antimicrobial Agents and Chemotherapy. Washington, DC: American Microbiology Society; 2005.

16. Lagos RMA, Espinoza A, Moene K, Hausdorff W, Ruttimann $\mathrm{R}$, et al. Population-based surveillance for suspected $(S)$ and radiologically-confirmed $(R x C)$ community acquired pneumonia (CAP) in children 1-35 months of age (MoA), in 6 municipalities (Mn) of the metropolitan region (MR), Chile. 5th International Symposium on Pneumococci and Pneumococcal Diseases 2006. Alice Springs, Elsevier.

17. Black S, Shinefield H, Fireman B, Lewis E, Ray P, Hansen JR, et al. Efficacy, safety and immunogenicity of heptavalent pneumococcal conjugate vaccine in children. Northern California Kaiser Permanente Vaccine Study Center Group. Pediatr Infect Dis J. 2000; 19: 187-95.

18. Black SB, Shinefield HR, Ling S, Hansen J, Fireman B, Spring D, et al. Effectiveness of heptavalent pneumococcal conjugate vaccine in children younger than five years of age for prevention of pneumonia. Pediatr Infect Dis J. 2002; 21 : 810-5.

19. WHO. Macroeconomics and health: investing in health for economic development. Report of the Commission on Macroeconomics and Health. Geneva: World Health Organization; 2001.

20. De la Hoz F, Higuera AB, Di Fabio JL, Luna M, Naranjo AG, de la Luz Valencia M, et al. Effectiveness of Haemophilus influenzae type $\mathrm{b}$ vaccination against bacterial pneumonia in Colombia. Vaccine. 2004; 23: 36-42.

21. WisloffT, Abrahamsen TG, Bergsaker MA, Lovoll O, Moller $\mathrm{P}$, Pedersen MK, et al. Cost effectiveness of adding 7-valent pneumococcal conjugate (PCV-7) vaccine to the Norwegian childhood vaccination program. Vaccine. 2006; 24: 5690-9.

22. De Wals P, Petit G, Erickson LJ, Guay M, Tam T, Law B, et al. Benefits and costs of immunization of children with pneumococcal conjugate vaccine in Canada. Vaccine. 2003; 21: 3757-64.

23. Beutels P, Thiry N, Van Damme P. Convincing or confusing? Economic evaluations of childhood pneumococcal conjugate vaccination: a review (2002-2006). Vaccine. 2007; 25: 135567.

24. Simoes E, Cherian T, Chow J, Shahid-Salles S, Laxminarayan $\mathrm{R}, \mathrm{T}$. J. Acute respiratory infections in children. In: Jamison D, Breman J, Measham A, Alleyne G, Claeson M, Evans D, et al. (eds). Disease control priorities in developing countries. 2nd ed. New York: The World Bank; 2006. p. 483-97. 